\title{
Likidite Bankaların Kârlılığını Etkileyen Faktör mü? Ampirik Bir Çalışma
}

\author{
Prof. Dr. Turan Öndeş ${ }^{1}$ \\ Öğretim Görevlisi Asfia Binte Osman ${ }^{2 *}$
}

Geliș tarihi: 11.02 .2020

Kabul tarihi: 12.04 .2020

\section{Atıf bilgisi:}

IBAD Sosyal Bilimler Dergisi

Sayı: $7 \quad$ Sayfa: $393-402$

Yıl: 2020 Dönem: Güz

This article was checked by Turnitin. Similarity Index $11 \%$

Bu makalede araştırma ve yayın etiğine uyulmuștur.

\section{${ }^{1}$ Atatürk Üniversitesi, Türkiye, turanondes@hotmail.com ORCID ID 0000-0001-6580-7372}

${ }^{2}$ International Islamic University Chittagong, Bangladesh, asfiasoh@gmail.com. ORCID ID 0000-0002-0163-9821

\section{* Sorumlu yazar}

\section{ÖZ}

$\mathrm{Bu}$ çalışma, likiditenin Türk bankalarının karlılığı üzerinde herhangi bir etkisi olup olmadığını değerlendirmeye çalışmaktadır. Çalışmayı Türkiye Bankalar Birliği web sitesinden toplanan panel verilerini kullanarak yürütüyoruz. 31.12.2017 tarihi itibariyle aktif büyüklügüne göre Türkiye'nin en büyük 10 bankasını seçtik ve 20082017 yılları arasındaki 10 yıllık verileri kullandık. Kredi Mevduatı, Mevduat Varlığı, Toplam Varlığa (TA) Likit Aktif, Kısa Vadeli Borçlara Likit Aktif ve Likit Aktiflere Mevduat ile Mevduat Olmayan Kaynaklar Oranını likidite ve ortalama ROA ile ortalama ROE karlılığın vekili olarak kabul edilmiştir. Verileri korelasyon analizine dayanarak analiz ediyoruz. Ayrıca EViews 10 desteğiyle Rasgele Etki regresyon modelini de uyguladık. Çalışmamız, Kredi Mevduat Oranı ve Likit Aktif - Toplam Varlık oranının ROE ve ROA üzerinde önemli olumsuz etkileri olduğunu ortaya koymaktadır. Mevduat Varlık Oranı, ROA üzerinde önemli ve olumsuz bir etkiye sahip olmakla birlikte, ROE üzerinde önemsiz ve olumsuz bir etkiye sahiptir. Ayrıca, Likit Aktiflerin Mevduat ve Mevduat Olmayan Kaynaklara Oranı, ROE üzerinde istatistiksel olarak anlaml fakat olumsuz etki göstermektedir; aksine ROA üzerinde önemsiz fakat olumlu bir etki göstermektedir.

Anahtar Kelimeler: Likidite, Karlılık, Bankacılık Sektörü, Türkiye. 


\title{
Is Liquidity An Influencing Factor for Profitability of Banks? An Empirical Study
}

\author{
Prof. Dr. Turan Öndeş ${ }^{1}$ \\ Lec. Asfia Binte Osman ${ }^{2 *}$
}

First received: 11.02 .2020

Accepted: 14.04 .2020

\section{Citation:}

IBAD Journal of Social Sciences

Issue: 7

Pages: $393-402$

Year: 2020

Session: Summer

This article was checked by Turnitin. Similarity Index $11 \%$

\footnotetext{
${ }^{1}$ Atatürk Üniversitesi, Türkiye, turanondes@hotmail.com ORCID ID 0000-0001-6580-7372
}

${ }^{2}$ International Islamic University Chittagong, Bangladesh, asfiasoh@gmail.com.

ORCID ID 0000-0002-0163-9821

\section{* Corresponding Author}

\begin{abstract}
This study attempts to assess whether liquidity has any influence on the profitability of Turkish banks or not. We conduct the study using panel data collected from the website of the Association of Banks of Turkey. We select 10 biggest banks of Turkey based on asset size as on 31.12.2017 and used 10 years' data ranging from 2008-2017. Loan Deposit, Deposit Asset, Liquid Asset to TA, Liquid Asset to Short- term Liability and Liquid Assets to Deposits and Non-Deposit Resources Ratio has been considered as a proxy of liquidity and average ROA and average ROE has been considered as a proxy of profitability. We analyze the data based on correlations analysis. We also run the Random effect regression model in our study with the support of E-Views 10. Our study reveals that Loan Deposit Ratio and Liquid Asset to Total Asset ratio do have a significant negative influence on both ROE and ROA. Deposit Asset Ratio does have a significant and negative influence on ROA but an insignificant and negative influence on ROE. Moreover, Liquid Asset to Deposit and Non-Deposit Resources Ratio shows a statistically significant but negative influence on ROE; in contrast an insignificant but positive impact on ROA.
\end{abstract}

Keywords: Liquidity, Profitability, Banking Sector, Turkey. 


\section{INTRODUCTION}

Profitability is the main concern for all kind of business entities. There are many internal and external factors that influence profitability. Generally, profitability refers to the ability to generate yields from the business activity; but bank profitability refers to the capability of banks to produce revenue greater than the costs incurred (Athanasoglou et al., 2005). Liquidity is also another factor that helps business entities keep operational activities going smoothly. It is defined as the degree or the ease an asset is converted to cash and traded at the fair market price Nwaezeaku (2006). From Banks' perspective, liquidity refers to the aptitude of the banks to preserve adequate funds so that it can satisfy its maturing obligations (Ibe, 2013).

Liquidity and profitability have always been a matter of concern for banks. Both factors are crucial for banks' existence. Chukwunweike (2014) explored a connection between liquidity and profitability. Generally, if a bank holds more cash it prevents the risk of bankruptcy, but it drives a bank to forgive earnings growth and vice versa. It gives rise to the question "Do banks need to prioritize profitability or liquidity?" In this issue, Bordeleau and Graham (2010) suggested not to hold much liquidity as it decreases profitability. It means that maintaining liquidity is important but in an appropriate amount; not too much or not too little.

A number of studies have been conducted in many countries measuring the influence of liquidity on profitability. Some studies found positive and some studies found negative correlations. Again in some studies, the correlation was strong and in some it was weak. Also there exists study found no significant influence of one on the other.

The key objective of this study is to assess the influence of liquidity on the profitability of Turkish banks. To the best of our knowledge, there is no previous study presenting the association between liquidity and profitability of banks covering the time frame of our study. Thus, successful completion of the study will facilitate a number of things. First, it will help to unveil the sort of relationship between liquidity and profitability in the most recent years. Second, this study is based on the banking sector, a very important financial intermediary in the economic system of the country. The results of the study are expected to contribute to the decision making of the banks related to liquidity decisions and increasing profitability. Third, to the best of our knowledge, previous studies on this issue in Turkey is not remarkable, therefore this study will ensure an added contribution in the literature; therefore, will be helpful to the policymakers and interest groups in understanding the importance of their relationships and formulating policies regarding liquidity and profitability accordingly. Finally, this study covered several ratios in measuring the relationship. Thus, it can be considered as a study in a bigger framework in respect of ratios covered for the study.

In the study five Liquidity ratios (Loan Deposit, Deposit Asset, Liquid Asset to TA, Liquid Asset to Short Term Liability and Liquid Assets to Deposits and Non-Deposit Resources Ratio) and two profitability ratios (Return on Assets and Return on Equity) have been used as a proxy of liquidity and profitability determinants respectively. We consider Liquidity ratios as predictors and profitability ratios as outcome variables. We collect 10 years' panel data from the Association of Banks of Turkey. We provide general information through some descriptive statistics. After that, we measure the correlation of liquidity ratios with the profitability ratios. Finally, we run the random effect model through EVIEWS 10 to make the study more noteworthy to the readers. Besides these, this study has a limitation on its sample size and period of study as it covers only 10 years' data of ten (10) selected banks. So more studies can be conducted in a broader framework.

\section{LITERATURE REVIEW}

Profitability and liquidity are very sensitive and crucial issues for banks. That is why these topics are always under close observation and a worthy research topic for the researchers. A good number of studies have been conducted on this topic beforehand. Molyneux and Thornton (1992) conducted a study on European countries for the period of 1986 to 1989. They did a regression test and their result did show a negative association between profitability and liquidity. They also uttered that cash holding results in reduced profitability as it contains opportunity cost. Bordeleau and Graham (2010), in their 
working paper on large banks of the United States of America and Canada, investigated the influence of liquid assets on the profitability. They uttered that holding some liquid assets causes an increase in profitability but holding more causes a decrease in profitability. The result is in support of keeping a moderate amount of liquidity holding.

A number of studies have been conducted in Nigeria too. For example, a study by Adebayo et al. (2011) revealed a significant association of liquidity with profitability in their study on Nigerian commercial banks. In another study by Olagunju et al. (2011), researchers discovered a negative correlation between liquidity and profitability (if there is a rise in liquidity it causes a fall in profitability and vice versa). The authors used both primary and secondary data for their study and applied the Pearson correlation technique accordingly. Afterward, Ibe (2013) also revealed the influence of liquidity and profitability of Nigerian banks conducting a study on three randomly selected sample banks by regression analysis and concluded recognizing liquidity as a big issue for the banking industry of Nigeria. More recently, a study by Ikeora \& Werigbelegha (2016) also reveals a positive association between liquidity and profitability. They use Time series data from 1989 to 2013 and run the Ordinary Least Squares (ODL) method to make the analysis.

A number of studies have been conducted in several other countries too. Lartey et al. (2013) discovered the association between liquidity and profitability of registered banks in the Ghana Stock Exchange. Using the data from 2005-2010, the authors found a very weak but positive association between liquidity and profitability. Al-Nimer, et al. (2013) in their study on fifteen Jordanian banks using data from 20052011 and applying simple regression model revealed that profitability in Jordanian banks is highly influenced by liquidity. Again, Sulieman Alshatti (2015) investigated the effect of liquidity management on the profitability of commercial banks of Jordan. The study covered thirteen commercial banks using data ranging from 2005-2012. Through regression analysis, they revealed that a rise in quick ratio and investment ratio results in a rise in the profitability of the banks too. Whereas, a rise in the capital ratio and the liquid assets ratio directs a fall in profitability. A study was done by Salim and Bilal (2016) on Oman, another Middle East country revealed a mixed result in their investigation on liquidity and profitability relationship. The authors conducted the study on four banks using five years' data ranging from 2010 to 2014. With multiple regression analysis, they discovered a significant correlation between the bank's Loans/ Total assets, Loans/ Deposits \& short term liabilities, Bank loans to customer deposits/ Total assets and return on assets. On the other hand, there was an insignificant relationship between the Bank's liquidity position and net interest margin (NIM).

A number of studies have been found in Asian countries too. Arif and Anees (2012) investigated twentytwo banks of Pakistan from 2004 to 2009 to see the influence of liquidity risk on profitability. Their study showed that liquidity risks have a noteworthy influence on the profitability of the banks. Some other studies are also available in Pakistan. Maqsood et al. (2016) carried on research on 8 (eight) different banks. They found the existence of the expressive effect of liquidity on the profitability by using data ranging from 2004-2015 and employing regression and correlation tests in the study. Ahmad (2016) also measured the association of liquidity ratios with profitability. The author applied correlation and regression tests in the study and found a weak positive relationship between liquidity and profitability. Nabeel \& Hussain (2017) inspected the effect of liquidity on profitability using 10 (Ten) years data ranging from 2006-2015. They discovered a positive association of interest coverage, capital adequacy and quick ratio with profitability and a negative association of current ratio with profitability through correlation and regression analysis.

Akter and Mahmud (2014) inspected the relationship between liquidity and profitability. They employed correlation and regression analysis and found no significant relationship between liquidity and profitability in Bangladesh.

Recently, a study by Almaqtari et al. (2019) in India examined the factors of profitability using panel data for the period of 2008 to 2017. Applying pooled, fixed, random effect models and panel correction standard error they find many factors that have a significant impact on profitability and liquidity ratio is one of them. 
There are a number of studies in this area, but the results are inconclusive. Authors are interested to investigate the standing of Turkey in respect of profitability and liquidity relationship as to the best of the authors' knowledge no studies have been conducted based on Turkey coving as many ratios as they are interested to use as a proxy of liquidity and profitability measures in their study.

\section{METHODOLOGY}

\subsection{Sample Size}

This study has been conducted on 10 top banks of Turkey based on asset size. The banks have been selected from the list shared by the Association of Banks of Turkey (https://www.tbb.org.tr) as on 31.12.2017.

Table 1. Bank Names With Their Respective Asset Size

\begin{tabular}{ccc}
\hline Sl. No. & Bank Name & $\begin{array}{c}\text { Total Asset Size as on 31.12.2017 (in } \\
\text { Million TL) }\end{array}$ \\
\hline 1 & T.C. Ziraat Bank & 434,275 \\
2 & Turkiye Is Bank & 362,353 \\
3 & Turkiye Garanti Bank & 325,232 \\
4 & Ak Bank & 316,031 \\
5 & Turkiye Halk Bank & 305,351 \\
6 & Yapi ve Kredi Bank & 297,810 \\
7 & Turkiye Vakifler Bank & 270,572 \\
8 & QNB Finas Bank & 125,857 \\
9 & Deniz Bank & 121,048 \\
10 & Turk Economi Bank & 85,758 \\
\hline
\end{tabular}

Source: Association of Banks of Turkey

\subsection{Data Design and Variable Determination}

10 years' data ranging from 2008 to 2017 has been used to calculate the necessary ratios for the study. To conduct the study some liquidity ratios and profitability ratios have been taken into consideration. The ratios are presented in table no. 2 :

Table 2. Liquidity Ratios

\begin{tabular}{|c|c|c|c|}
\hline Sl. No. & Ratio (Variable) Name & Formula & Notation \\
\hline 1 & Loan Deposit Ratio & $\begin{array}{l}\text { Total Loans and Advances / Total } \\
\text { Deposits*100 }\end{array}$ & LDR \\
\hline 2 & Deposit Asset Ratio & Total deposits / Total Assets*100 & DAR \\
\hline 3 & Liquid Asset to TA Ratio & Liquid assets /Total Assets*100 & LATAR \\
\hline 4 & $\begin{array}{l}\text { Current Ratio/ Liquid } \\
\text { Asset to Short term } \\
\text { Liability Ratio }\end{array}$ & $\begin{array}{l}\text { Liquid assets / Short term } \\
\text { Liability*100 }\end{array}$ & LASTLR \\
\hline 5 & $\begin{array}{lcr}\text { Liquid } & \text { Assets } & \text { to } \\
\text { Deposits } & \text { and } & \text { Non- } \\
\text { Deposit Resources Ratio }\end{array}$ & $\begin{array}{l}\text { Liquid Assets / Deposits and } \\
\text { Non-Deposit Resources*100 }\end{array}$ & LADNDRR \\
\hline
\end{tabular}

Among the sample ratios, only Loan Deposit ratio and Deposit Asset ratio was calculated by the authors from the provided data. The rest of the ratios were directly picked up for analysis from the data bank of the Association of Banks of Turkey. 
Table 3. Profitability Ratios

\begin{tabular}{llll}
\hline Sl. No. & Variable Name & Formula & Notation \\
\hline 1 & Return on assets & Net Income/ Total Assets*100 & ROA \\
2 & Return on equity & Net Income/ Total Equity*100 & ROE \\
\hline
\end{tabular}

To conduct the study available average ROA and average ROE have been collected from the data bank of the Association of Banks of Turkey.

Liquidity ratios have been considered as independent or predictor variables and profitability ratios have been considered as dependent or outcome variables.

\subsection{Econometric methodology}

We estimate the influence of liquidity variables on the profitability using 10 years' panel data of 10 top Turkish banks based on the total assets size. We express the general form of the model in the following way:

$$
\pi_{\mathrm{it}}^{*}=\mathrm{a}+\beta \mathrm{X}_{\mathrm{it}}^{*}+\varepsilon_{\mathrm{it}}
$$

Here, $\pi_{i t}^{*}$ indicates profitability, $\alpha$ is the intercept, $\beta$ is the coefficient to be estimated, $X_{i t}^{*}$ is the vector of liquidity and $\varepsilon_{i t}$ is the error term.

We can express the aforesaid variable as:

$$
\text { Profitability }=f \text { (Liquidity) }
$$

The elaborated form of the variable is:

$$
(\mathrm{ROA}, \mathrm{ROE})=f(\mathrm{LDR}, \mathrm{DAR}, \mathrm{LATAR}, \mathrm{LASTLR}, \mathrm{LADNDRR})
$$

We design our specified model as:

$$
\begin{aligned}
& R O A=\alpha+\beta L D R_{i t}+\gamma D A R_{i t}+\delta L A T A R_{i t}+\vartheta L A S T L R_{i t}+\lambda L A D N D R R_{i t}+\varepsilon_{i t} \\
& R O E=\alpha+\beta L D R_{i t}+\gamma D A R_{i t}+\delta L A T A R_{i t}+\vartheta L A S T L R_{i t}+\lambda L A D N D R R_{i t}+\varepsilon_{i t}
\end{aligned}
$$

In the above equations, $i$ indicates individual sample bank, $t$ indicates the year, $\beta, \gamma, \delta, \vartheta$ and $\lambda$ are the respective coefficients of the explanatory variables and $\varepsilon$ is the error term. Elaborations of other variables (dependent and independent) are already mentioned in table 2 and table 3 while presenting both profitability and liquidity ratios.

We estimate both fixed and random effect regression models. Moreover, we run the Hausman test to decide if fixed or random effect fits the study. In conducting the test, we assume that:

Null Hypothesis: The preferred model is Random Effect

Alternative Hypothesis: The model is Fixed Effect

According to the decision rule prescribed by Hausman; we decide to run The Random Effect on both the models as the p-values are larger than 5\% and we cannot reject the null hypothesis.

\section{RESULTS OF THE STUDY}

\subsection{Descriptive Analysis of the Study}

Table 4 demonstrates the descriptive statistics of the variables. From the table, we can see that the Loan Deposit ratio has the uppermost average value. Whereas, ROA has the lowermost average value. Likewise, the Loan Deposit ratio has the highest standard deviation and ROA has the lowest standard deviation. Loan Deposit Ratio has also the greatest difference between Maximum and minimum value. 
Table 4. Descriptive statistics of the sample data used in the study

\begin{tabular}{cccll}
\hline Variable Names & Minimum & Maximum & Mean & Std. Deviation \\
\hline $\begin{array}{c}\text { Loan Deposit Ratio } \\
\text { Deposit Asset } \\
\quad \text { Ratio }\end{array}$ & 73.00 & 110.20 & 99.5700 & 11.65409 \\
$\begin{array}{c}\text { Liquid Asset to TA } \\
\quad \text { Ratio }\end{array}$ & 19.70 & 34.40 & 27.4600 & 4.90783 \\
$\begin{array}{c}\text { Liquid Asset to Short } \\
\text { term Liability Ratio } \\
\text { Liquid Assets to }\end{array}$ & 33.60 & 62.80 & 48.3900 & 8.59812 \\
$\begin{array}{c}\text { Deposits and Non- } \\
\text { Deposit Resources }\end{array}$ & 22.80 & 41.80 & 33.8100 & 5.38092 \\
$\quad$ Ratio & & & & \\
$\quad$ Return on Assets & 1.20 & 2.10 & 1.7800 & .30111 \\
Return on Equity & 12.40 & 22.40 & 16.3400 & 3.18126 \\
\hline
\end{tabular}

\subsubsection{Correlation Analysis}

Table 5 demonstrates the summary of the results of the correlation analysis between predictor variables and outcome variables. Loan Deposit ratio exhibits a strong negative correlation with average ROA. It suggests that if Loan Deposit ratio increases average ROA decreases and vice-versa. Remaining four liquidity ratios, i.e. Deposit Asset ratio, Liquid Asset to TA ratio, Liquid Asset to Short Term Liability ratio and Liquid Assets to Deposits and Non-Deposit Resources ratio are showing weak positive correlation with average ROA, i.e. if there is an increase in the liquidity then there is also an increase in the average ROA. Moreover, the Loan Deposit ratio has a strong negative correlation with average ROE. Again, the Deposit Asset ratio has a strong positive correlation with average ROE. Liquid Asset to Short Term Liability ratio has a weak negative correlation ROE. The remaining predictor variables in the study (Liquid Asset to TA ratio and Liquid Assets to Deposits and Non-Deposit Resources ratio) are also showing a very weak negative relation with ROE.

Table 5. Correlation Matrix

\begin{tabular}{llllllll}
\hline & DAR & LADNDR & LASTLR & LATAR & LDR & ROA & ROE \\
\hline DAR & 1.000 & -0.169 & -0.260 & -0.096 & -0.807 & 0.347 & 0.604 \\
LADNDR & -0.169 & 1.000 & 0.810 & 0.649 & -0.254 & 0.220 & -0.000 \\
LASTLR & -0.260 & 0.810 & 1.000 & 0.768 & -0.100 & 0.117 & -0.107 \\
LATAR & -0.096 & 0.649 & 0.768 & 1.000 & -0.218 & 0.083 & -0.046 \\
LDR & -0.807 & -0.254 & -0.100 & -0.218 & 1.000 & -0.556 & -0.693 \\
ROA & 0.347 & 0.220 & 0.117 & 0.083 & -0.556 & 1.000 & 0.879 \\
ROE & 0.604 & -0.000 & -0.107 & -0.046 & -0.693 & 0.879 & 1.000 \\
& & & & & & & \\
\hline
\end{tabular}

\subsection{Empirical Findings of the Study}

Before we do regression analysis, we employ the Hausman test in our study to decide whether random or fixed effect model is suitable for our study for unbiased estimates. The probability of Chi-Sq statistic for model one (ROA) and model 2 (ROE) are 0.09 and 0.57 which is greater than at $5 \%$ level of significance, therefore, we cannot reject the null hypothesis i.e. random effect is appropriate. Hence, we applied the random effect model for getting consistent estimates. Furthermore, to check the cross-section correlation among the regressors we applied the cross-section dependency test in our study. The results of the Breusch-Pagan LM test, Pesaran Scaled LM test and Pesaran CD test (Table 6) show that the probability value in all cases is less than 5\% level of significance therefore we reject the null hypothesis and conclude that cross-section correlation prevails in the data. 
Table 6. Cross-Section Dependency Test

\begin{tabular}{lll}
\hline & ROE (Statistic) & ROA (Statistic) \\
\hline Breusch-Pagan LM & $72.601^{* * *}$ & $97.671^{* * * *}$ \\
Pesaran Scaled LM & $2.909^{* * * *}$ & $5.552^{* * * *}$ \\
Pesaran CD & $4.938^{* * *}$ & $7.015^{* * *}$ \\
\hline
\end{tabular}

${ }^{* * * *}$ Significant at $1 \%$ level

For estimating the random effects, we used panel corrected standard errors methods to account for cross section correlation for robust estimates. We did our estimation in E-View 10 software which accounts for all stated econometric specification issues.

The result of our regression test is also summarized below in table no. 7. Loan Deposit Ratio has a significant negative influence on both ROE and ROA. It means that if Loan Deposit Ratio increases the ROE and ROA of the bank's decreases. Liquid Asset to Total Asset ratio is also showing a significant negative influence on both ROE and ROA. It means that if Liquid Asset to Total Asset ratio increases, both ROA and ROE decrease significantly. Deposit Asset Ratio is showing a negative influence on ROA and ROE. Therefore, if Deposit Asset Ratio increases it will result in a decrease in ROE and ROA. Here the influence is significant in the case of ROA but insignificant in the case of ROE. Moreover, Liquid Asset to Deposit and Non-Deposit Resources Ratio is screening a significant negative impact on ROE but insignificant positive impact on ROA. Lastly, Liquid Asset to Short Term Liability Ratio is showing a positive influence on both ROE and ROA but the influence is insignificant in both the cases. Generally, it can be summarized as liquidity ratios mostly affect profitability ratios negatively. The result is similar to the studies done by Molyneux and Thornton (1992) and Olagunju et al. (2011) which showed a negative influence of liquidity on profitability. The reason behind the outcome might be holding huge liquid assets for serving customers' demand. The result of the study is in support of the statements by Molyneux and Thornton (1992), Goddard et al (2004) and Bordeleau and Graham (2010) that holding high liquidity hampers the profitability.

Table 7. Random effect model of the regression results showing the impact of liquidity variables on profitability regressors.

\begin{tabular}{lcc}
\hline \multicolumn{1}{c}{ Regressor } & ROE & ROA \\
\hline C & $51.512^{* * *}$ & $6.171^{* * *}$ \\
& $(14.227)$ & $(1.697)$ \\
Loan Deposit Ratio & $-0.242^{* * *}$ & $-0.025^{* * *}$ \\
& $(0.048)$ & $(0.005)$ \\
Deposit Asset Ratio & -0.077 & $-0.026^{*}$ \\
& $(0.132)$ & $(0.014)$ \\
Liquid Asset to Total Asset Ratio & $-0.144^{*}$ & $-0.018^{*}$ \\
& $(0.076)$ & $(0.010)$ \\
Liquid Asset to Short Term Liability Ratio & 0.014 & 0.005 \\
Liquid Asset to Deposit and Non-Deposit & $(0.041)$ & $(0.006)$ \\
Resources Ratio & $-0.086^{*}$ & 0.001 \\
& $(0.051)$ & $(0.005)$ \\
Adj $\mathrm{R}^{2}$ & & \\
Prob (F-statistic) & 0.46 & 0.31 \\
\end{tabular}

$* * *$ significant at $1 \%, * *$ significant at $5 \%$ and $*$ significant at $10 \%$

Additionally, adjusted R-squired value reveals that only $46 \%$ and $31 \%$ of the change in profitability ratios (ROE \& ROA respectively) can be explained by liquidity ratios. It can be considered as logical because there are many other factors; some are specific to the banks and some are macroeconomic that have an impact on the profitability of banks. 


\section{CONCLUSION}

The study attempted to measure the influence of liquidity on the profitability of Turkish banks. It was conducted on 10 (ten) biggest banks of Turkey based on asset size using panel data of 10 (ten) years ranging from 2008 to 2017. Loan Deposit, Deposit Asset, Liquid Asset to TA, Liquid Asset to Short Term Liability and Liquid Assets to Deposits and Non-Deposit Resources Ratio has been used as a dimension of liquidity and average ROA and ROE has been used as a dimension of profitability. Our extensive analysis reveals that Loan Deposit Ratio and Liquid Asset to Total Asset ratio do have a significant negative influence on both ROE and ROA. Deposit Asset Ratio does have a significant and negative influence on ROA but an insignificant and negative influence on ROE. Moreover, Liquid Asset to Deposit and Non-Deposit Resources Ratio shows a statistically significant but negative influence on ROE; in contrast an insignificant but positive impact on ROA. Our overall study shows that the liquidity position of the banks has an adverse effect on profitability. This might be because banks are holding liquidity more than their necessity.

In the future, more studies can be conducted on this topic using a larger sample size, including more or different ratios. Studies can also be carried on different types of banks like government banks, private banks, multinational banks, Islamic banks, etc. individually or collectively by comparing the standing and nature of the relationship of these factors between different types of banks.

\section{REFERENCES}

Adebayo, M., Adeyanju, D. \& Olabode, S. (2011), Liquidity management and commercial banks' profitability in Nigeria. Research Journal of Finance and Accounting, 2(7/8), 24-38. Retrieved from http://www.iiste.org on January 1st, 2020.

Ahmad, R. (2016). A Study of relationship between liquidity and profitability of standard charterd bank Pakistan: Analysis of financial statement approach. Global Journal of Management And Business Research, 16(1-C), 76-82. Retrieved from https://journalofbusiness.org/index.php/GJMBR/article/view/1927 on January 1st, 2020.

Akter, A., \& Mahmud, K. (2014). Liquidity-profitability relationship in Bangladesh banking industry. International Journal of Empirical Finance, 2(4), 143-151.

Al Nimer, M., Warrad, L., \& Al Omari, R. (2015). The impact of liquidity on Jordanian banks profitability through return on assets. European Journal of Business and Management, 7. Retrieved from Online website: www.iiste.org on January 1st, 2020.

Almaqtari, F. A., Al-Homaidi, E. A., Tabash, M. I., \& Farhan, N. H. (2019). The determinants of profitability of Indian commercial banks: A panel data approach. International Journal of Finance \& Economics, 24(1), 168-185.

Arif, A., \& Nauman Anees, A. (2012). Liquidity risk and performance of banking system. Journal of Financial Regulation and Compliance, 20(2), 182-195.

Athanasoglou, P. P., Brissimis, S. N. \& Delis, M. D .(2005). Bank-specific, industry- specific and macroeconomic determinants of bank profitability. Working Paper, 25, 4-35. Retriewed from

https://mpra.ub.uni-muenchen.de/32026/1/Bank-specific.pdf on January $1^{\text {st }}, 2020$.

Bordeleau, É., \& Graham, C. (2010). The impact of liquidity on bank profitability. Working Paper, 38, 1-22. Retriewed from https://www.bankofcanada.ca/wp-content/uploads/2010/12/wp1038.pdf on January $1^{\text {st }}, 2020$.

Chukwunweike, V. (2014). The Impact of liquidity on profitability of some selected companies: the financial statement analysis (FSA) approach. Research Journal of Finance and Accounting, 5(5), 81-90. Retrieved from https://www.iiste.org/Journals/index.php/RJFA/article/view/11414/11746 on January 1 st, 2020. 
Goddard, J., Molyneux, P. \& Wilson, J.O.S. (2004). Dynamics of growth and profitability in banking. Journal of Money, Credit and Banking, 36, 1069-1090.

Ibe, S. O. (2013). The impact of liquidity management on the profitability of banks in Nigeria. Journal of Finance and Bank Management, 1(1), 37-48.

Ikeora, J. J. E., \& Werigbelegha, A. P. (2016). Liquidity management and banksâ $€^{\mathrm{TM}}$ profitability In Nigeria (1989-2013): An empirical analysis. Journal of Business Management and Economics, 4(7), 01-05

Lartey, V. C., Antwi, S., \& Boadi, E. K. (2013). The relationship between liquidity and profitability of listed banks in Ghana. International Journal of Business and Social Science, 4(3), 48-56.

Maqsood, T., Anwer, M. A., Raza, A., Ijaz, M., \& Shouqat. U. (2016). Impact of liquidity management on profitability in banking sector of Pakistan. International review of management and business research, 5(2), 643-652.

Molyneux, P., Thornton, J., 1992. Determinants of European Bank profitability. Journal of Banking and Finance, 6, 1173-1178

Nabeel, M., \& Hussain, S.M. (2017). Liquidity Management and its impact on banks profitability: A perspective of Pakistan. International Journal of Business and Management Invention, 6(5), 28-33.

Nwaezeaku, N. C. (2006). Theories and practice of financial management. Owerri: Ever Standard Publishing.

Olagunju, A., Olanrewaju, A., Olabode, D., \& Samuel, O. (2011). Liquidity management and commercial banks' profitability in Nigeria. Research Journal of Finance and Accounting, 2(7-8), 24-39.

Salim, B. F., \& Z. O. Bilal. (2016). The impact of liquidity management on financial performance in Omani banking sector. International Journal of Applied Business and Economic Research, 14(1), $545-565$

Sulieman Alshatti, A. (2015). The effect of the liquidity management on profitability in the Jordanian commercial banks. International Journal of Business and Management, 10(1), 62-71. 